特 別

講 演

小規模選鉱工場の設計建設と

その後の経過について

一田老および大峰選鉱工場建設の経過より一

$\begin{array}{llll}\text { 蒲 } & \text { 生 } & \text { 達 } & \text { 一 }^{*} \\ \text { 古 } & \text { 川 } & \text { 久 } & \text { 人 }^{* *} \\ \text { 石 } & \text { 井 } & \text { 五 } & \text { 郎 } \\ \text { 檜 } & \text { 森 } & \text { 安 } & \text { 彥 }\end{array}$

\title{
Construction and Practice of a Small Scale Milling Operation
}

Tatsuichi GAMO, Hisato FURUKAWA, Goro ISHII, Yasuhiko HIMORI

\section{1. 序言}

処理量 $500 \mathrm{t}$ /日程度の小規模選鉱工場を経済的、合理 的にかつ短期間で建設するととは、大規模選鉱工場の建 設と異なつたむずかしさがある。しかあ大工場なみに、 選鉱成績の向上之配置人員の縮減のため調節、制御、秤 量などの自動化器機を採用し、さらに防寒設備を必要と する場合の、建設費はますます割高となる。

筆者らは、昭和 35 年 6 月 36年 2 月大峰選鉱工場 $(250$ $\mathbf{t} /$ 日)、昭和36年 6 月 37年 1 月虫老選鉱工場 $(700 \mathrm{t} /$ 日）の設計建設を実施した。

大峰は処女地の新建設であるが、田老は昭和 36 年 5 月 の大山火事で焼失した選鉱工場の復旧工事で、被災残存 のコンクリート構造物、鉄骨残骸などを利用しなければ なら制約があつたが、全般的には共通の考え方で設計 建設を実施し、8〜9ケ月の短期間で建設を完了した。

\section{2. 共通の考え方}

大峰鉱山は、比較的選鉱の容易な鉱石で銅精釷のみを 産し、田老鉱山は、緻密な結晶の複雑硫化鉱から銅、鉊 亜鉛、硫化鉄の各精鉱を採取するため、選鉱工場の規 模、方式は当然異なり、両者を同一に論ずるととは他少 無理な点ああるが、闭者に共通な点をあげてみる。

\footnotetext{
受理 昭和 39 年 9 月 28 日 第 32 回例会における特別講演

*ラサ工業株式会社本社生産部長

**ラサ鉣業・タイ国

*** 田老鉣業所選鉣課長

**** 大峰鉱業所選鉱係長
}

(1) 両鉱山はいずれあ寒冷地にあり、冬期の気温は大峰 でー $20^{\circ} \mathrm{C} 、$ 田老で $-12^{\circ} \mathrm{C}$ 位に下がるため、凍結事故 を幾度す経験しており、特に防寒対策について考慮を 払つた。また偶然にあ両者の建設開始時が 6 月で、整 地土木工事が終り、建築の仕上工事が冬期にかかるた め、建築速度はできるだけ早いとと、凍結期中であ工 事が容易であること、防火構造であることを条件にし た結果、軽量鉄骨およびスレート板、石育ボードを用 いる乾式構造法を採用した。しかし田老においては、 工期の関係で被災後の残存鉄骨をそのまま利用した鉄 骨コンクリート柱や、一部鉄筋コンクリート構造、中 空ブロック壁も併用した。

建物の鉄骨類は、すべて都市の工場で加工製作した 上トラック輸送し、現地では突合せ部分の取付のみと して建築速度を早めることにつとめた。

（2）建物の防寒構造は、第 1 図の如き参考資料を検討の 上決定した。

すなわち大峰では屋根を「亜鉛引鉄板互棒葷、ポリ エチレンシート、木毛板、フレキシブルシート」の 4 種の張り合せ、側壁を「小波スレート、フレキシブル シートまたは大平板」の 2 重の張り合せとした。田老 においては、屋根を「亜鉛引鉄板互棒葺、ポリエレチ ンシート、木毛板」の 3 種の張り合せ、側壁は「スレ 一ト板」とした。採光は、ポリエチレンプレート 2 重 張天空と、同一様式の固定空により、かつ解放できる 空はスチールサッシュとした。破砕場は他工程への粉 塵飛散を防止するため仕切壁を設け、極寒地の大峰で は暖房効果をあげるため、磨鉱浮選場と接する他工程 

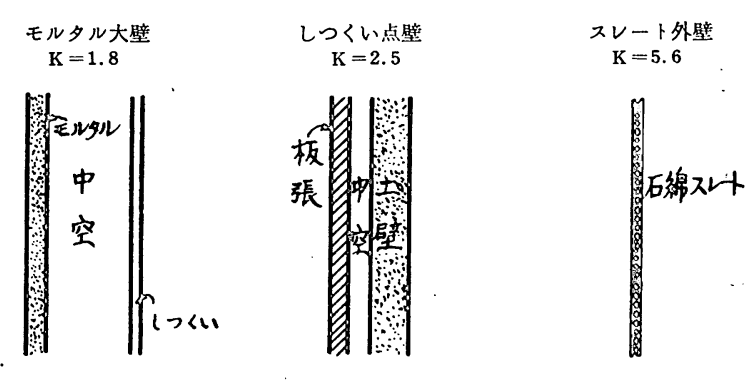

スレート大壁
$\mathrm{K}=1.8$

コンクリート壁
$\mathrm{K}=3.1$
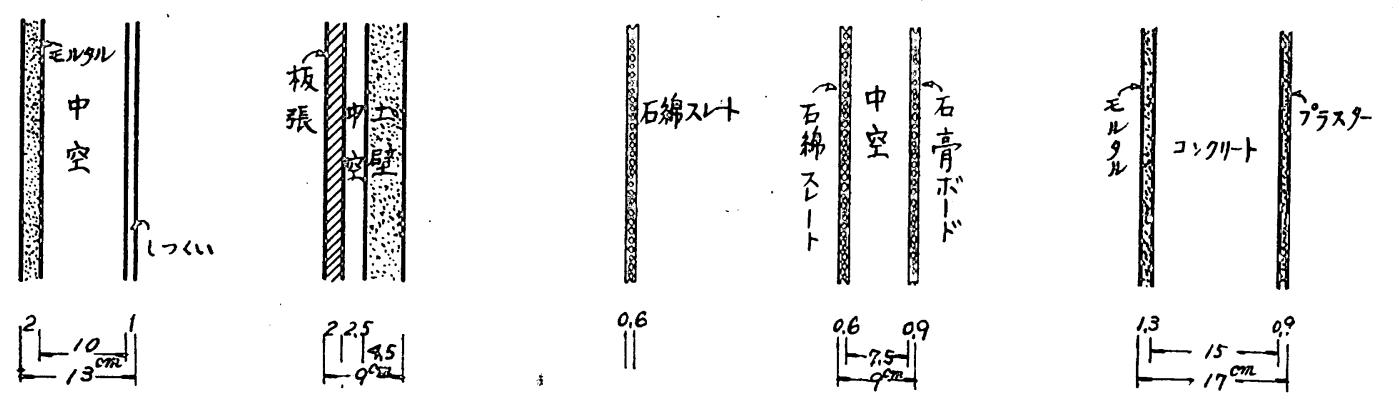

$\|^{0,6}$
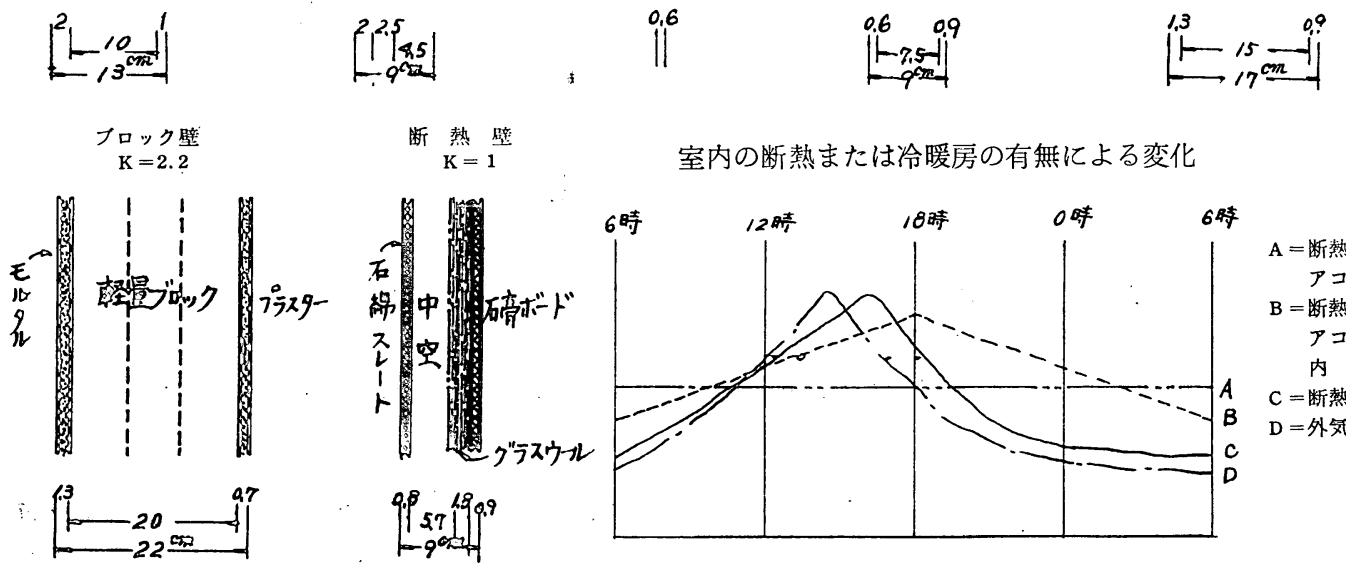

室内の断熱または冷暖房の有無による变化

第 1 図 各種外壁の熱量流率（新建築Vol 37 No. 5$)\left(\mathrm{K}: \mathrm{kcal} / \mathrm{m}^{2} \mathrm{hC} \mathrm{C}^{\circ}\right)$ の比較

との間にそれぞれ空付壁を設けた。暖房は大峰は蒸気 暖房、田老は熱風暖房を設けた。乙の結果冬期の室内 外の気温差は、従来の $2 \sim 3{ }^{\circ} \mathrm{C}$ 加 $10 \sim 15^{\circ} \mathrm{C}$ 亿上昇 し、休転時であ室内温度は零度以下に下らず、凍結事 故はほとんどなくなつた。

（3）主要鉱石搬出坑道地なみより下部に破砕場を階段式 に設けるための落差を得ることができない地形なので 受入ホッパ、粗砝機は半地下式とし、粗砕機の下部か ら総延長 $100 \mathrm{~m}$ のベルトコンベャを設け、坑口と同一 水準に設けた中砕眝鉱舎まで持ちあげるようにした。 したがつて受入場、破研場、磨鉱場はほぼ同一水準で 横に広がり、その下部に浮選場、滤過場、精鉱眝鉱舎 が 1〜2段に設けられた半平面式選鉱工場となつた。

（4）将来の増処理に備えて、建物面積に若干の余裕を之 り、大型ジョウクラッシャ、ボールミル、シックナ、 精鉱貯鉱舎などの寸法決定については、最小限の補足 改善で、大峰は $400 \mathrm{t} /$ 日、田老は1,000 t / 日、位の増 処理可能の含みをむつた。ただし大峰においてはその 後建物を若干拡張し、ロッドミルを採用し破砕磨鉱工 程を改善するととにより現在 $650 \mathrm{t} /$ 日を処理しており $1,000 \mathrm{t} /$ 日位まで処理可能となつた。

(5) 調節、制御、科量などの自動化器機の設備はまつた く不満足であるが

（イ）粗鉱、精鉱の秤量はメリックスケールを設置し流
量の自記、哀隔指示、積算量の印字などの装置をつ けた。またボールミル給鉱の制御には、いろいろ精 巧な装置があるが、小選鉱工場においては価格的に 建設費中に占める機械代の割合が大きすぎ採用しに くいので、田老で考案した機械式コンスタントフィ 一ダ (第 2 図) で制御し、さらにメリックスケール で総流量を自記し、設定量をはずれた場合警報を発 する装置をつけた。

(口) 電動機のスイッチ類は、破砕、磨鉱、浮選など工 程別に同一スイッチ板に集約し、電流計、時間計の ほかに記録式電力計を備え、その記録を䉓力消費管 理のほかに 運転状況を知る資料にするととを試み た。

(价自記式 $\mathrm{pH}$ メータを備えたが、将来 $\mathrm{pH}$ 調節剂フィ 一ダに連動させる予定である。 記装については現在次のでとき計画をむつている。

(1) 工業用テレビによる遠方監視

（2）螢光 $X$ 線分析器の迅速分析に上る現場操業管理 （昭和39年 3 月から実施し、精鉱品位の上昇実収 率の向上に大きい効果をあげている)

（3）磨鉱回路の給鈗量、添加水量の制御

（4）その他機械装置の無人運転

（6）受入ホッパの容積は比較的小さくしたが、粗砕した 鉱石を入れる中間ホッパとボールミルビンはともにそ 

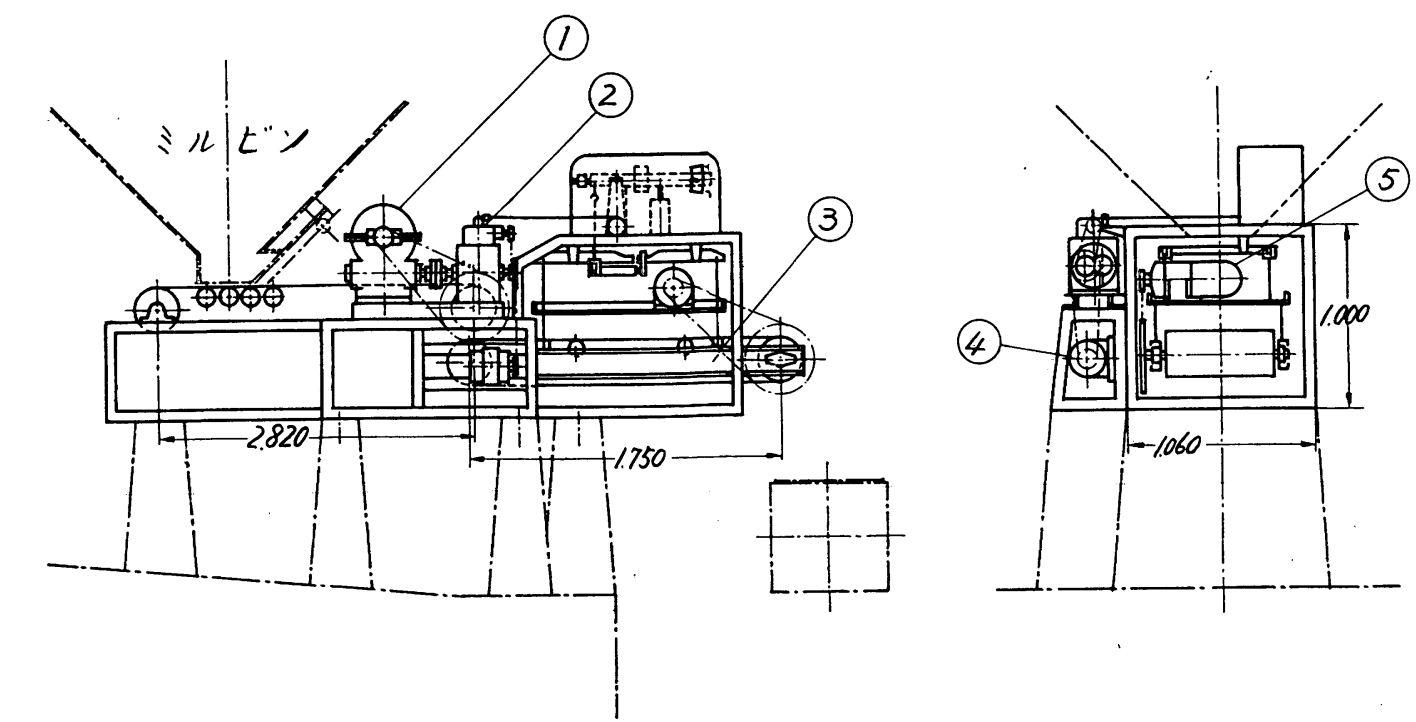

仕様 (1) 300\#ウォーム減速機（2) O.A.C.3\#リンクコーン変速機（3) コンスタントウェヤー、材質：高力アルミニウム合金

(1) モーター; 日立 $0.75 \mathrm{~kW} \times 4 \mathrm{P}$ (5) ギャードモーター：日立、 $0.4 \mathrm{~kW} \times 1 / 30$ ヘルトフィーダー速度、 $5 \mathrm{~m} \sim 10 \mathrm{~m} / \mathrm{min}$

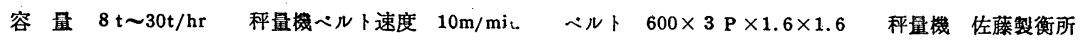

第2図機械式コンスタントフィーダ

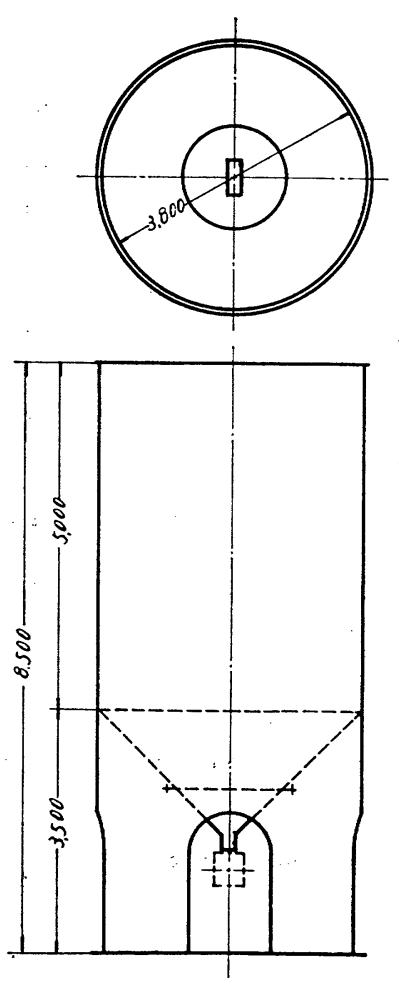

容積 $63.8 \mathrm{~m}^{3}$
の容量を大きくし、 貯鉱の際シャトルコ ンベヤにて鉱質を平 均化することにし た。大峰ではブレシ デング効果をあげる ため直径に比較して 高さの大きな円筒型 のビン(第 3 困)を設 けた。田老の場合工 期の関係で被災した コンクリート製ビン をそのまま使用し た。

(7) 小規模選鉱工場で ミル給鉱をつくる場 合、設備が簡単で效 率のよいインペラブ レ一カを採用し、再 破砕は一挙に行なえ るように設計した。 すなわち一段目の破 砕機に、大峰では S R V 25ギャレスクラ ッシヤを、田老では $24^{n} \times 15^{\prime \prime}$ シングル・
トッグル・ジョウクラッシャを用いたが、後者におい てのみ、3 呎コーン・クラッシャを予備として設置し た。とれの産物は、ロータ $760 \mathrm{~mm} \phi \times 930 \mathrm{~mm}$ のイン ペラ・ブレーカ、2 台にリップルフロ・スクリーンを 前置して給鉱、その産物はフルイ機に繰り返す閉路式 として、80\%サイズを6〜 $7 \mathrm{~mm}$ としている。これら の破砕系へは貯鉱舎から、Vベルト変速機を備えたべ ルトフィーダ (第 4 図) で量質とも平均化して給鉱し 効果をあげている。

しかし処理量が増加するにつれてインペラブレーカ は部品の点検、取り替えが頻繁となり運転効率が低下 するので大選鉱工場ではロッドミルなどを採用し処理 量を増加するほうが有利であり、現在大峰ではインペ ラ・ブレーカを廃止し、ロッドミルを採用、ミル給鉱 80\%サイズを、 $20 \mathrm{~mm}$ とし効率をあげている。また四 老では前段の破砕機を廃止し、一挙にインペラ・ブレ 一力に給鉱する方式に変更し、80 $\mathrm{t} /$ 時間を処理して おり、さらにロッドミル採用による破砕場の合理化を 計画中である。

（8）塊鉣の輸送については、バケット・エレベータの芳 しい成績を持つていなかつたととと、サーペンテック ス・コンベャその他の新型輸送機は工期の関係で検討 期間がなく採用しなかつた。したがつてベルト延長が 少々長くなつても全部ベルトコンベヤによることとし たため、大峰18本、田老34本とベルトコンベヤが多く なつた。標準化した箱型フレームを工場生産し、現場 


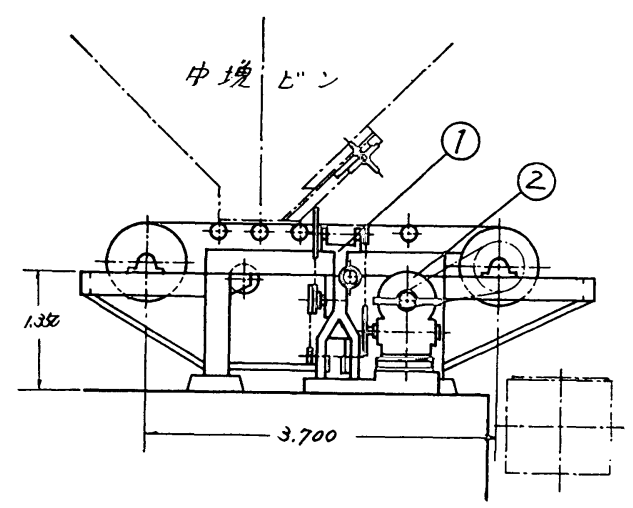

第 Q図 Vベルト変速フィーダ

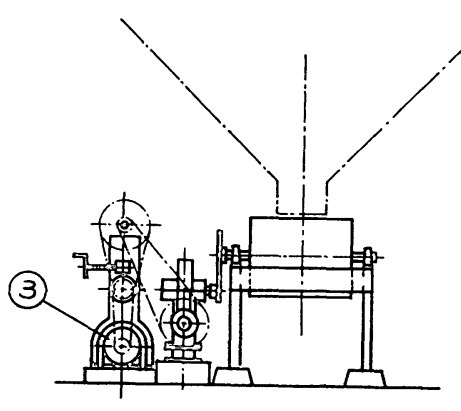

$24 "$ ヘルトフィーター

(1) 三木式変速プーリーM L-210

(2) 300 \#ウォ一ム減速機 $1 / 45$

(3) モーター; $0.75 \mathrm{~kW} \times 6 \mathrm{P}$ ヘルト $600 \times 5 \mathrm{P} \times 4.8 \times 1.6$
の人員で施行した。

建築土木工事あ、大峰 では一括元請方式によら ず、末端の請負業者に別 々に分割請負とし、一部 常侓むした。田老におい ては、時間的制約之社宅 その他厚生施設の復旧む 併行して行なわねばなら なかつたので、2〜3の 元請業者に分割発注し、 建築設計む大要を指示依 頼した。
では、これをボールト継ぎするだけとし、工期の短縮 をはかつた。

(9) 計画処理量の割合には、オーバ・サイズのトリコン ミルを採用し、七ル寸法は自由に選んだ。すなわちセ ル・ライナ内径で大峰は 8 呎、田老は 9.5 呎、回転数 は臨界速度の65\%とし、ボール運動を改善するためス 一パ・ウェーブライナを使用した。

(10) 2 段分級、2 段磨鉱を採用し大峰では 180 メッシュ ・グラインディング、田老では 200 メッシュ・グライ ンディングを目標とするが、2段分級機としてセント リフロ分級機を使用した。セントリフロ分級機の機能 については、いまだ検討すべき点も多いが、田老では $\mathrm{Cu}+\mathrm{Pb} 、 \mathrm{Zn}+\mathrm{Sp}$ 精鉱の -325 メッシュ以下の練い分 級にも使用している。

(11) 粗粒単体の目的鉱物を早期回収するため、1 次磨鉱 回路に浮選機を設けた。

(12) 浮選機は比較的槽の深い $1,200 \mathrm{~mm} 、 \mathrm{EW}$ 型浮選機 を採用し、1 槽当たり好理量を大きくとつた。

(13) サンドポンプはすべてワーマンポンプを採用、田老 では合計38台を使用している。

(14) 精鉱瀘過はシックナを前置した単胞式ドラムフィル タを用いたが、田老では被災した、デスクフィルタも 修理して使用している。脱水成績は前者に比べてよく ない。

（15）照明は水銀灯を主とし、補助に螢光灯、白熱灯を使 用し主要箇所の照度は100〜180ルクスとした。

(16) 建築単価が比較的高いため、修繥用あるいはてれに 類似のスペースはできるだけ少なくし、選鉱工場内の 運搬はすべて天井走行クレーンによることとした。

(17) 建設費を下げる手段の一つとして、選鉱機械類のほ とんどを自家設計し、部品で購入の上、据付位置で組 み立てるなどし、あるあのは自家製作も行なつた。機 械の組立、据付はすべて田老、大峰の選鉱、工作関係

\section{3. 建 設 置}

建設費は、処理鉱量 $\mathrm{t} /$ 日当たり大峰は、665,000円、 田老は、634,000 円である。ただし両者とも第 1 表に示 す項目を含んでおり、選鉱関係のみではそれぞれ 450,000 円、500,000円 である。建設工事の諸元は第 2 表に示す とおりである。

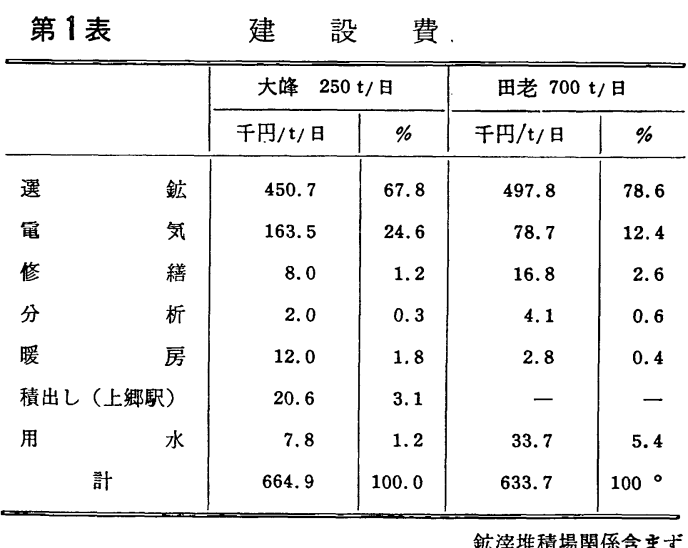

その後増設を続け、現在 $650 \mathrm{t} /$ 日となつている大峰の 当初以来の累計企業費は、処理量 $\mathbf{t} /$ 日当たり 370,000 円 となつている。

特に建物の土木建築費は選鉱関係工事費の約 $30 \%$ を占 めるから、レイアウトに留意し極力余剩な建物面積の縮 減に努めるべきであろう。

現在、処理能力当たり建物面積は、大峰 $3.3 \mathrm{~m}^{2} / \mathrm{t} /$ 日 由老 $5.5 \mathrm{~m}^{2} / \mathrm{t} /$ 日である。

\section{6. 建設後の経過}

建設計画は、社業の要請と鉱況によつて逐次拡大処理 の方針に対処して立案、現在大峰においては、きわめて 少ない企業費で開発当時の約 3 倍強の、650 $\mathrm{t}$ /日処理と 
建 設工事諸 元

\begin{tabular}{|c|c|c|}
\hline & 大 & 田 \\
\hline 設 備 馬 力 & $549 \mathrm{~kW}$ & $3,100 \mathrm{~kW}$ \\
\hline 建 物 総 面 積 & $1.841 \mathrm{~m}^{2}$ & $4,392 \mathrm{~m}^{2}$ \\
\hline 銅 材 建物拉壁 & $196 \mathrm{t}$ & $544.2 t$ \\
\hline 設 備 & $243 \mathrm{t}$ & $* \quad 443.4 \mathrm{t}$ \\
\hline 計 & $439 \mathrm{t}$ & $987.6 \mathrm{t}$ \\
\hline セメント & $395 \mathrm{t}$ & $1,633.2 \mathrm{t}$ \\
\hline 設 備 & $177.5 t$ & $592.8 \mathrm{t}$ \\
\hline 計 & $572.5 \mathrm{t}$ & $2,226 \mathrm{t}$ \\
\hline コンクリートプロック & & ב \\
\hline 毛 & $1,900 \mathrm{~m}^{2}$ & $6,286 \mathrm{~m}^{2}$ \\
\hline 石綿 ス $v$ - 卜板 & 1,800 枚 & 1, 615枚 \\
\hline 石保ボード 及平板 & 3,200 枚 & - \\
\hline タ1ナマ 1 1 & . & $1,144.4 \mathrm{~kg}$ \\
\hline 稼働 延人員 & 17,560 人 & 33,812 人 \\
\hline I & 260日 & 245日 \\
\hline
\end{tabular}

* 機械本体除く

なり、田老む、800 $\mathrm{t}$ /日処理が可能なとてろまで増加し ている。

建設当初と現在との成績その他の比較を第 $3 \sim 5$ 表に 示す。（選鉱工場系統図、機械配置図省略）
第 5 表

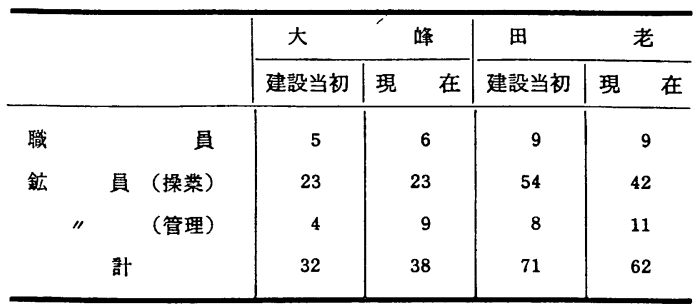

\section{5. むすひ}

以上、大峰、田老におりる小規模選鉱工場の設計、建 設に当たつての筆者らの経験を述べた。設備の充実と建 設費の抑制という楯の両面のような問題と取り組み、で き上がつた今日、いろいろと反省すべき点む多く、誠に 汗顔の至りである。諸賢ので批評をいただければ幸いで ある。

この発表は、当社社長吉見䢅殿ので承認を得て行なう あのであります。両選鉱工場とあ、当社専務取締役松村 貞三殿ので指導のもと、村井係長、田口主任、その他両 釷山の、選鉱、工作関係の建設に従事された各位、両鉱 業所の所長殿はじめ職員御一同の大なるで協力により完 成致したあので、各位に心から感謝の意を表わします。

第 3 表

大峰 選 鉱工場

（1 日当たり）

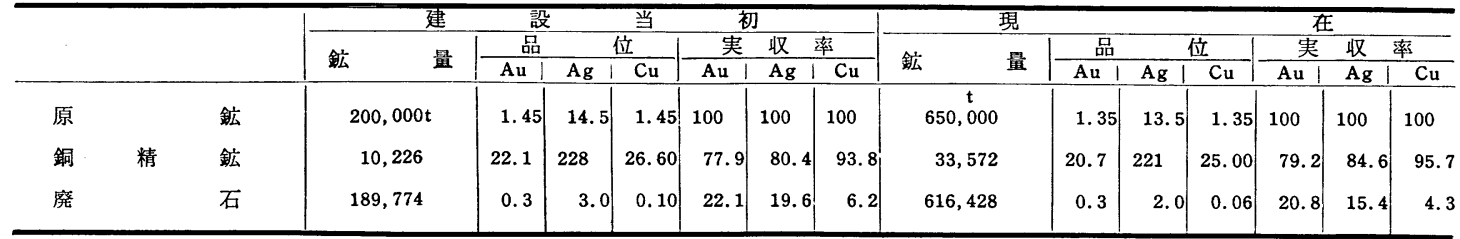

第 4 表

田老選鉱工場

(1 日当たり)

\begin{tabular}{|c|c|c|c|c|c|c|c|c|c|c|c|c|c|c|c|c|c|c|}
\hline & \multicolumn{3}{|c|}{ 建 } & \multicolumn{2}{|l|}{ 設 } & \multicolumn{4}{|c|}{ 初 } & \multicolumn{5}{|c|}{ 現 } & \multicolumn{4}{|c|}{ 在 } \\
\hline & \multirow{2}{*}{ 鉱 量 } & \multicolumn{2}{|c|}{ 品 } & \multicolumn{2}{|c|}{ 位 } & \multicolumn{2}{|c|}{ 実 } & \multicolumn{2}{|c|}{ 收率 } & \multirow{2}{*}{ 鉱 量 } & \multicolumn{2}{|c|}{ 品 } & \multicolumn{2}{|c|}{ 位 } & \multicolumn{2}{|c|}{ 奏 } & \multicolumn{2}{|l|}{ 率 } \\
\hline & & $\mathrm{Cu}$ & $\mathrm{Pb}$ & $Z_{n}$ & $\mathrm{~S}$ & $\mathrm{Cu}$ & $\mathrm{Pb}$ & $Z_{n}$ & $\mathrm{~s}$ & & $\mathrm{Cu}$ & $\mathrm{Pb}$ & $\mathrm{Zn}$ & $\mathrm{s}$ & $\mathrm{Cu}$ & $\mathrm{Pb}$ & $Z_{n}$ & $\mathrm{~S}$ \\
\hline 銨 & $\begin{array}{c}t \\
t \\
650,000\end{array}$ & 0.39 & 3.30 & 7.70 & 16.00 & 100. & 100 & 100 & 100 & $\begin{array}{c}t \\
t 20,000\end{array}$ & 0.40 & 2.60 & 7.80 & 18.50 & 100 & 100 & 100 & 100 \\
\hline 銅 精. 鉱 & 6,560 & 25.00 & 8.00 & 8.00 & 36.00 & 65.0 & 2.4 & 1.0 & 2.3 & 8,160 & 25.00 & 6.00 & 4.00 & 33.00 & 71.0 & 2.6 & 0.6 & 2.0 \\
\hline 鉛，精 鉱 & 27,880 & 0.90 & 60.00 & 11.00 & 22.00 & 9.9 & 78.0 & 6.1 & 5.9 & 23,080 & 0.40 & 60.00 & 11.00 & 23.00 & 3.1 & 74.0 & 4.5 & 4.0 \\
\hline 亜鉛精 鉱 & 77,340 & 0.50 & 1.50 & 55.00 & 33.00 & 15.0 & 5.4 & 85.0 & 24.5 & 93,450 & 0.40 & 2.00 & 54.50 & 34.00 & 12.8 & 10.0 & 90.7 & 23.9 \\
\hline 硫化铁精鉱 & 124,350 & 0.05 & 0.40 & 0.50 & 46.00 & 2.4 & 2.3 & 1.2 & 55.0 & 183,510 & 0.13 & 0.70 & 0.50 & 45.00 & 8.3 & 6.8 & 1.6 & 62.0 \\
\hline 淈合精鉱 & 7,000 & 1.00 & 20.00 & 25.00 & 36.00 & 2.8 & 6.5 & 3.5 & 2.4 & 2,470 & 1.00 & 15.00 & 10.00 & 30.00 & 0.7 & 2.0 & 0.5 & 0.6 \\
\hline 石 & 406,870 & 0.03 & 0.28 & 0.38 & 2.52 & 4.9 & 5.4 & 3.2 & 9.9 & 409,330 & 0.03 & 0.21 & 0.29 & 2.47 & 4.1 & 4.6 & 2.1 & 7.5 \\
\hline
\end{tabular}

